\title{
Application of Therapeutic Jurisprudence: A Different Approach to Punishment in Kenya
}

\author{
Eric Kariuki*
}

\begin{abstract}
A critical role of the State is the regulation of crime by maintaining law and order and, at the same time, punishing crime. This paper seeks to address the retrogressive way crime is punished in Kenya. The author proposes that this can be rectified through the application of the doctrines of therapeutic jurisprudence (TF), a theory first propounded by David Wexler when he tried to create a solution to the treatment of mental health victims in criminal courts. This paper takes his theories and applies them to the Kenyan context. In addressing these issues, this paper shall first look at the existing theories behind punishment, with focus on incarceration as the primary form of punishment, and highlight their flaws. It shall then look at TF and explain how it can be infused into the Kenyan legal system. In doing so, the paper argues, the effectiveness of punishment can be greatly increased.
\end{abstract}

\section{Introduction}

This paper is split into two parts. The first goes into the existing theories of punishment, highlights their characteristics and elaborates on their faults. In particular, it deals with the retributive and utilitarian theories. The second part contains the discourse on therapeutic jurisprudence (TJ), specifically on how it is practiced around the world and what forms it could take in the Kenyan jurisdiction.

All the established theories as cited here fall under the banner of criminal jurisprudence. According to Michael Freeman, 'Jurisprudence (is) the study of general theoretical questions about the nature of laws and legal systems, about the relationship of law to justice and morality and about the social nature of law'. 'This is as distinguished from jurisprudence as the use of case law in judicial

\footnotetext{
* The author is an LL.B student at the Strathmore University Law School in Nairobi, Kenya.

1 Freeman M, Introduction to jurisprudence, 9ed, Sweet \& Maxwell, London, 2014, 2.
} 
decisions which comes from the French la jurisprudence meaning 'that part of the positive or actual law built up by judicial decision rather than enacted and laid down in statutes or in codes: what Bentham called "judge-made law". ${ }^{2}$

The concept spotlighted in this paper is jurisprudence as the philosophical view of the law. To understand this, one should interpret it from three key perspectives. The law has been established-that is the when. It has been established by the law makers responsible- that is the how. Jurisprudence is the why. Regarding how crime is punished, or justice effected, this article shall elaborate on the main theories in criminal law that establish punishment as a whole and highlight their flaws.

\section{Theories Underlying Punishment}

\section{i. The utilitarian view}

Utilitarianism as a whole is more concerned with morality than it is with the law. However, the two are closely linked. ${ }^{3}$ According to Jeremy Bentham, its main proponent, the law ought to promote the good of society. In a more precise manner, he states that we, as humans, seek pleasure and avoid pain. His entire moral theory is that 'the greatest happiness of the greatest number is the measure of right and wrong. ${ }^{4}$ Throughout the history of modern philosophy, this has been one of the most compelling approaches to philosophy. ${ }^{5}$ It rightly follows that it had an enormous influence on the law.

It is apt to first deliberate on what Bentham meant by 'greatest happiness' and how it is effected through the law. There is general disagreement in utilitarianism as to what Bentham meant by 'greatest good'. ${ }^{6}$ However, what suits us best is that which he himself propounded. Bentham states that happiness is the 'net balance of pleasure over pain'. ${ }^{7}$ This view of happiness was not new as its roots can be derived from hedonism. Epicurus, its main proponent, similarly viewed pleasure as the absence of pain. ${ }^{8}$ Aside from their definitions of happiness, the

\footnotetext{
Tur R, 'What is jurisprudence?' 28 (111) The Philosophical Quarterly, 1978, 1.

Miltner C, 'Law and morals' 10 (1) Notre Dame Law Review, 1934, 1.

Bentham J, A fragment on government, Cambridge University Press, 1776, 1.

Miller J and Miller R, 'Jeremy Bentham’s Panoptic Device’ 41 (1) the MIT Press, 1987, 6.

Harrod R, 'Utilitarianism revised' 45 (178) Oxford University Press, 1936, 138.

Bentham J, An introduction to the principles of morals and legislation, Library of Economics and Liberty, 1789, 2.

8 Epicurus, Letters to menoecus, 1.
} 
similarities of the philosophies of Epicurus and Bentham stop here. ${ }^{9}$

Punishment, as defined by Bentham, is key in understanding utilitarianism in respect to criminal jurisprudence. ${ }^{10}$ Bentham defines punishment as 'an evil resulting to an individual from the direct intention of another, on account of some act that appears to have been done or omitted'. ${ }^{11}$ He goes on to say that 'punishment is an evil, that is, a physical evil; either a pain, or a loss of pleasure. ${ }^{12}$ Punishment is the loss of pleasure and Bentham defines happiness as the absence of pain. We then have to find a way to reconcile these two apparent opposites: that a utilitarian world should lack pain and at the same time justify punishment.

A utilitarian view of the law, correspondingly, is that the law should promote the good of society as a whole. As to how it relates to punishment, it was put best in the following manner:

'While the law of torts requires that wrongdoers compensate their victims for the harm done, the criminal law provides for the punishment of a wrongdoer. Since punishment involves some form of pain, utilitarians demand that there be some gain possible that more than makes up for the pain inflicted on the wrongdoer. For the utilitarian, the question of whether the existence of a system of criminal law can be justified thus comes down to the question of whether the practice of inflicting pain on criminals produces gains for society that more than make up for the pain'.13

The whole basis of utilitarianism is that the pleasure should outweigh the pain experienced by the majority. It follows that when it comes to utilitarianism in terms of punishment, if there is an aspect of pain, which in this case is unavoidable, it has to somehow translate to the good of society. The good has to be of a magnitude that compensates for the pain caused and converts it into pleasure experienced by the greatest majority of that society.

Utilitarianism aims to achieve a number of ends through punishment. First, there is general deterrence. One of the objectives of punishing crime has been

$9 \quad$ Epicurus founded hedonism and Bentham established utilitarianism. While both theories generally involve the concept of happiness, they do so in widely different ways. Epicurus said that pleasure can be derived from friends and freedom See Epicurus, Letters to menoecus. Bentham developed the felicific calculus which was his way of determining what the greatest good was. This formula calculated the intensity, length, certainty or uncertainty, proximity or remoteness, fecundity and purity. See Bentham, An introduction to the principles of morals and legislation, 22.

10 See Draper T, 'An introduction to Jeremy Bentham's theory of punishment' 5(1) Journal of Bentham Studies, 2002, 1.

11 Bentham J, The rationale of punishment, 1830, Robert Heward, 1.

12 Bentham J, The rationale of punishment, 2.

13 Altman A, Arguing about law: An introduction to legal philosophy, Wadsworth Publishing Company, 1996, 116. 
to discourage others from doing so. ${ }^{14}$ The view has been that if someone is punished for committing a certain crime then the state is justified in punishing them if it deters others from committing similar acts. This, utilitarianism proposes, is the good for society.

Another aim of utilitarianism is incapacitation. While general deterrence aims at discouraging society from committing crime, incapacitation aims at stopping the persons themselves from committing the crime. It reduces the chances of the perpetrator committing the crime again. According to Altman, 'by isolating the wrongdoer from society and carefully regulating his conduct around the clock, imprisonment decreases his opportunities for additional crime'. ${ }^{15}$

Incapacitation merges with general deterrence since seeing criminals being imprisoned encourages society to avoid the acts the criminal perpetrated. They work in tandem because the severity of imprisonment is an effective deterrence against the perpetration of crime. This has shown, however, to be wrong in that

incapacitation is a compelling reminder of the danger of an ideology of crime control rooted in little more than political rhetoric. However, as long as public opinion connects increased levels of imprisonment with reduced levels of crime, policy makers will stifle any impulse to implement the kind of research... suggested. ${ }^{16}$

Utilitarianism is reflected quite clearly, as a motivation for punishment, in the Kenyan legal system. The pain of punishment has to translate into the good. This appears quite clearly in the Kenyan jurisdiction by virtue of the importance we place on incarceration; the prison rate has been steadily climbing for a number of years. ${ }^{17}$ The reason imprisonment is so heavily relied upon is that we imprison in the hopes of 'disabling a persistent offender from committing further crimes and thereby averting any danger he would cause to society. ${ }^{18}$

While the utilitarian view of punishment has featured prominently in criminal justice systems across all jurisdictions, it has its shortcomings. First, one of the main aims of utilitarianism is general deterrence. The assumption has been

14 See Carlsmith K and Darley J, 'Why do we punish? Deterrence and just deserts as motives for punishment' 83(2) Journal of Personality and Social Psychology, 2002, 284.

15 Altman, Arguing about law: An introduction to legal philosophy, 117.

16 See Sharkey C, 'Out of sight, out of mind: Is blind faith in incapacitation justified?' 105(5) The Yale Law Journal, 1996, 1437.

17 Kiarie J, 'Petty offenders jam prisons as congestion hits crisis level' The Standard Newspaper, 2 May 2015 -<http://www.standardmedia.co.ke/article/2000160773/petty-offenders-jam-prisonsas-congestion-hits-crisis-level> on 9 December 2016.

18 Wesonga J, 'Kenya's Penal System Vis-À-Vis the Theories of Punishment: Analysis' published, University of Nairobi, Nairobi, 2000, 7. 
that punishment deters others from committing crime. However, when a clear distinction is made between the severity of punishment as deterrence to crime and the certainty of punishment as deterrence to crime, this notion proves to be wrong. A study conducted by a number of researches showed that the perceived certainty of legal action was an effective deterrence but the severity of punishment was not as effectual. ${ }^{19}$ What this means is that general deterrence as a justification for punishment only stands if the focus is on the certainty of punishment. In Kenya, the flaw is particularly evident as there has been a focus on stern as opposed to effective punishment. ${ }^{20}$

Second, incarceration is an ineffective method of preventing recidivism. Simply locking up the accused and letting them out a stipulated amount of time later does not mean that they will not commit the crime or any other crimes again. This is the intrinsic weakness of the incarceration system. Nothing stops the perpetrator from reverting back to their criminal ways if nothing further is done. ${ }^{21}$ This is more so if this lifestyle was a source of their livelihood. Incapacitation has its own problems even under the scope of the Kenyan legal system. In fact, 'harsh prison conditions in developing countries like Kenya are mostly characterised by overcrowding and congestion, poor diet, degrading clothing and beddings, lack of clean water, poor sanitation, infectious diseases ... among other vices'. ${ }^{22}$ These are a few of the many weaknesses of incarceration.

This theory manifests itself in Kenya in that courts rely on incarceration quite heavily.

\section{ii. The retributive view}

The foundations of retributivism can be traced to Immanuel Kant, the eighteenth century German philosopher. He justified it on moral and philosophical grounds. Unlike utilitarianism where the justification of punishment was to promote good, Kant believed that criminals should be punished because of their inherent wickedness. He states that 'judicial punishment can never be used merely as a means to promote some other good for the criminal himself or for society,

19 Anderson S, Chiricos G and Waldo G, 'Formal and informal sanctions: A comparison of deterrent effects' 25(1) Social Problems, 1997, 103 - 114.

20 Kinyanjui SM and Akech M, 'Toward structured sentencing in Kenya: A case for reform' 9(1) African journal for criminology and justice studies, 2016, 266.

21 Clear T, 'Backfire: When incarceration increases crime' 3(2) Journal of the Oklahoma Criminal Justice Research Consortium, 1996, 1-10.

22 Omboto J, 'The challenges facing rehabilitation of prisoners in Kenya and the mitigation strategies' 2(2) International Journal of Research in Social Sciences, 2013, 39. 
but instead it must in all cases be imposed on a person solely on the ground that he has committed a crime'.23

This translates quite well into the retributivist view that punishment is not warranted because of society but because of the crime committed. This view is built on the Just Deserts Theory which is that the severity of punishment should relate to the crime committed. ${ }^{24}$

A stellar example of this is the Rummel $v$ Estelle ${ }^{25}$ case decided by the Supreme Court of the US. The facts were: In 1973, a Texas jury convicted William Rummel of felony theft for obtaining 120.75 dollars under false pretences. The maximum sentence for that crime was then ten years' imprisonment. Rummel received a life sentence. There was no mistake. Under Article 65 of the Texas Penal Code, 'whoever shall have been three times convicted of a felony less than capital shall on such third conviction be imprisoned for life in the penitentiary'. Rummel had been convicted of a felony twice before. In 1964, he had been convicted of presenting a credit card with intent to obtain by fraud approximately eighty dollars; and in 1969, he had been convicted of passing a forged check for 28.36 dollars. The 1973 conviction was his third. The life sentence was mandatory. ${ }^{26}$

This decision was highly criticised since scholars viewed the punishment highly disproportionate to the crime committed. Even when Rummel appealed it was held, on a five-to-four majority that Rummel's sentence was not out of proportion to the crime committed. ${ }^{27}$ The retributive aim is to ensure that when punishment is meted, it should be proportionate to the crime committed. Not doing so, according to the retributivists, is injustice. ${ }^{28}$

The retributivist approach shall be deliberated upon on two limbs. Firstly, the positive limb is that those that are guilty of crime morally deserve punishment for the acts that they have committed. This is balanced with the second negative

23 Kant I, Metaphysical elements of justice, Hackett Publishing, 1797, 138.

24 Carlsmith K and Darley J, 'Why do we punish? Deterrence and just deserts as motives for punishment' 83(2) Journal of Personality and Social Psychology, 2002, 284.

25 Rummel $v$ Estelle (1980) The Supreme Court of the US.

26 Michael D, 'Just deserts for recidivists' 4(2) Criminal Justice Ethics, 1985, 29.

27 A case similar to this but with an almost contradictory verdict is that of Solem $v$ Helm (1983). The Supreme Court of the US that had similar facts but on appeal it was held that Helms sentence was cruel and unusual because the penalty was out of proportion to the crime. The distinction used by the court was there was a higher possibility of parole in Rummel and therefore imprisonment was justified.

28 See Weinreb L, 'Desert, punishment and criminal responsibility' 49(3) Law and Contemporary Problems, 1986, 47-80. 
limb which states that those who are innocent should not be punished. Retributivists believe that the purpose of the criminal justice system is to give the guilty what they deserve. What governs the retributivists is their longing for justice. However, this should not be confused with revenge. The differences between the two are made visibly apparent because what revenge involves is '(a) response(s) to wrongdoing (that) are personal responses to perceived wrongs to oneself and motivated by a concern with one's own self-regard or self-respect'. ${ }^{29}$ The aims of retributivism are not vindictive but are to punish the criminal because of their acts. It is not subjective in that the accused is not punished because of who their crime affected but because all that matters is that a crime was committed.

There are various justifications to retributivism. Firstly, punishment is a way of blaming and condemning the criminal. ${ }^{30}$ Secondly, punishment communicates to the criminal that they have inflicted wrongful harm on someone. ${ }^{31}$ When a criminal is reprimanded, it makes them aware that the acts that they committed were detrimental to those they affected and society at large. It makes it clear to the criminal that their acts did not happen in a vacuum. Lastly, crime gives the criminal an unfair advantage over others and punishment aims at correcting this. ${ }^{32}$ When a criminal commits a crime, he/she is essentially disregarding the law in a way that is to his/her benefit. Doing so is to the disadvantage of lawabiding members of society i.e. those who limit themselves to the bounds of the law for the sake of peace. It makes sense for the criminal to be reprimanded which, in some way, puts him back in place.

Despite its principles, retributivism has an Achilles' heel. When examined critically, it can justify the punishment of the innocent. Michael Moore gives justifications for where punishment of the innocent is warranted. He states it in the following manner:

'It is just not true that one should allow a nuclear war rather than killing or torturing an innocent person. It is not even true that one should allow the destruction of a sizeable city by a terrorist nuclear device rather than kill or torture an innocent person. To prevent such extraordinary harms extreme actions seems to me to be justified'. ${ }^{33}$

29 Murphy J and Coleman J, The philosopby of law, Roman and Allanheld Publishers, New Jersey, 1984, 126.

30 Altman A, Arguing about law: An introduction to legal philosophy, 119.

31 Altman A, Arguing about law: An introduction to legal philosophy, 120

32 Altman A, Arguing about law: An introduction to legal philosophy, 121.

33 Moore M, 'The moral wrath of retribution' in Schoeman F (ed), Responsibility, character, and the emotions, 1 ed, Cambridge University Press, 1987, 719. 
Extreme action, in view of preventing harm, justifies punishment of the innocent. While what Moore says is arguably true, in view of retributivism itself, this cannot stand. A key theory of punishment should not remain so if it justifies punishment of the innocent.

A key difference between the two theories is their views on the outcomes. For utilitarianism, punishment of the accused cannot be justified if all it did was cause pain. In fact, just causing pain would be against the entire principle. This pain has to be reflected in the good of the society. However, when it comes to retributivism, the accused deserves to be punished. It does not matter how this affects society. By virtue of committing the crime, punishment is warranted. Utilitarianism hopes that the punishment will result in the good of society while retributivism holds that since the crime has been committed punishment is deserved. One looks towards the future while the other, towards the past.

While the two theories, retributivism and utilitarianism, do have a bearing in punishment in the Kenyan criminal system, they have flaws we cannot ignore. The theory proposed in this article may not provide all the answers to the gaps left by these two established theories but it addresses all the substantive issues and provides alternatives. Amos Wako foreshadowed this argument when he said, speaking at a 1995 conference, that:

'In traditional Africa, a criminal who is taken to prison, or who is excommunicated from the society, is one who is actually beyond repair through societal means, or who has committed a major crime. What is recorded in our legal books as petty crimes by African standards were completely dealt with by the society. For example, if one stole a goat, the elders made sure another goat was paid and that was the end of the matter. The person who stole was so ashamed that he would not do it again'. ${ }^{34}$

\section{Applications of Therapeutic Jurisprudence}

\section{i. Background and history}

Therapeutic jurisprudence is a theory that addresses the flaws highlighted above. Its major aim is a radical shift from the focus on incarceration. What this means is that it would have different ways of treating offenders. What these mean is the focus of this article.

34 Wako A, 'Keynote address' Community Service Orders and the Administration of Criminal Justice in Kenya: Report of a Symposium on Extra-Mural Penal Employment, Nairobi, 14 December 1995, 10 from Stern V, 'An alternate vision: Criminal justice developments in non-western countries' 28(3) Social Justice, 2001, 92. 
The problem with the current system is that '(it) entails the morally unacceptable notion that innocent persons should sometimes be deliberately punished for their actions'. ${ }^{35}$ The 'sometimes' referred to relates to the utilitarian and retributive concepts we have in the Kenyan criminal system. The concept of TJ was established by David Wexler of the University of Arizona (Rogers College of Law) and the University of Puerto Rico (School of Law) in collaboration with Bruce Winick of the University of Miami (School of Law). Its origins are in Mental Health Law, particularly from a paper delivered to the National Institute of Mental Health in 1987 by Wexler. ${ }^{36}$

TJ is defined as 'an emerging field of law and social science inquiry that explores the role of the law in fostering therapeutic and anti-therapeutic outcomes'. ${ }^{37}$ It is a field of law that aims at moving the focus from incarceration as the answer in court systems to therapy as a form of treatment. As put by Vivienne Topp,

'it shifts the focus of 'the problem', manifested by the person's behaviour from punitive to rehabilitative... (This) means that criminal behaviour can be viewed in the context of any underlying physical, psychological, social or economic circumstances dealt with by effective social intervention rather than by harsher sentences". ${ }^{38}$

Even though there are similarities, rehabilitation is different from TJ. TJ looks at why the criminal committed the crime. In this way, it distinguishes itself from other theories as they start from the fact that the crime has been committed. Rehabilitation starts from the fact that a crime has already been committed. It is more effective to look at the reason the crime was committed and start to solve any underlying problems, as opposed to looking at the crime and determining how it can be punished. Rehabilitation is a part of therapeutic jurisprudence but it is only a fragment of the whole.

This section shall focus on how therapeutic jurisprudence is practised across the world and which forms of therapeutic jurisprudence are beneficial to Kenya.

\footnotetext{
35 Altman, Arguing about law, 118.

36 Wexler D and Winnick B, 'Therapeutic jurisprudence as a new approach to mental health policy analysis and research' 45(5) University of Miami Law Review, 1991.

37 Casey P, Rottman D, 'Therapeutic jurisprudence in the courts' Behavioural Sciences and the Law (2000), 445.

38 Topp V, 'Specialist courts - The impact upon the individual' Law Institute of Victoria Conference, Melbourne, 2002, 1.
} 


\section{ii. Application of TJ worldwide}

There are different ways TJ has been applied in different countries. By analysing these different approaches, we can better understand its doctrines and therefore apply them to the Kenyan legal system accordingly.

Australia applies TJ well. It has courts known as specialised courts or problem-solving courts that allow decision makers to deal with special issues through a framework outside the justice system in order to develop proper solutions. Generally, 'specialised courts represent a move away from focus on individuals and their criminal conduct to offenders' problems and their solutions'. ${ }^{39}$ They represent therapeutic jurisprudence in practice. Other countries, following this approach, include the US, Canada, and England, who particularly, though vaguely, express this through the development of problem solving courts. Specialised courts come in two main forms. First we have drug courts which are 'specifically designated to administer cases referred for judicially supervised drug treatment and rehabilitation within a jurisdiction'. ${ }^{40}$ There are also mental health courts where 'they attempt to identify mentally disordered defendants early in the criminal justice process, and, through a process of screening and referral to mental health agencies, attempt to prevent them being sent to prison if they do not represent a threat to the community. ${ }^{41}$

Specialised courts share a number of common elements essential to their function. First, the focus is on the case outcome. This means that they aim to achieve tangible outcomes for everyone within their scope. That is, the offender, the victims and society. Some of the things that these courts focus on are reductions in recidivism of the offender, reduced stays in foster care for any children affected by the offence, increased sobriety for addicts, and generally healthier communities. $^{42}$

Second, specialised courts try to effect a change in the legal system. This means that while re-examining individual case outcomes, specialised courts seek to change how government systems respond to problems like addiction, mental

39 Freiberg A, 'Problem-oriented courts: Innovative solutions to intractable problems?' 11(1) Journal of Judicial Administration, 2001, 11.

40 Freiberg A, 'Specialised courts and sentencing, probation and community corrections: Making the community safer' Perth, 23-24 September 2002.

41 Freiberg A, 'Specialised courts and sentencing, probation and community corrections: Making the community safer' Perth, 23-24 September 2002.

42 Berman G and Feinblatt J, 'Problem-solving courts: A brief primer' 23(2) Law \& Policy, 2001, 125140. 
illness and child neglect. They promote reform outside of the court house as well as within. ${ }^{43}$

Additionally, judicial monitoring is key to specialised courts. Here, problemsolving courts rely upon the active use of judicial authority to solve problems and to change the behaviour of litigants. Instead of passing off cases to other judges, probation departments and community-based treatment programmes, judges in problem-solving courts stay involved with each case throughout the post-adjudication process. ${ }^{44}$ This may seem to be impractical considering the judge to litigant ratio but the nature of specialised courts is that they accept a limited number of cases. Doing this enables judges to actively participate after the conclusion of the case. As Burke and Leben stated, 'people have a powerful urge and need to express their thoughts, experiences or even their questions ... the belief that one can go to legal authorities with a problem and receive a respectful hearing in which one's concerns are taken seriously is central to most people's definition of their rights as citizens in their democracy'. ${ }^{45}$

Further, problem-solving courts target a collaborative approach between the state and non-profit partners (that is, criminal justice agencies, social service providers, community groups, and others).$^{46}$ Lastly, problem-solving courts are very flexible. This means that often there may be non-traditional roles effected by some parties in this judicial procedure. Some problem-solving courts have altered the dynamics of the court-room, including, at times, certain features of the adversarial process. For example, problem-solving courts often engage judges in unfamiliar roles as well, asking them to convene meetings or broker relationships with community groups or social service providers. ${ }^{47}$ While this is a role-change, it is not drastic enough to brand this as restructuring the court system. Adversarial parties, in this instance, have other duties on-top of those they conventionally have. This is elaborated on further in this article.

By instituting these elements in the Kenyan legal system, Wexler's words would ring true. The problems with the legal system, particularly the criminal system, are that the retributivist view has a moral indifference to it that greatly hinders it effectiveness. For example, as referred to in the elements, in problem solving courts, judges stay involved with each case post-adjudication instead of

\footnotetext{
43 Berman G, 'Problem-solving courts: A brief primer', 125-140.

44 Berman G, 'Problem-solving courts: A brief primer', 125-140.

45 Burke $\mathrm{K}$ and Leben S, 'Procedural fairness: A key agreement in public satisfaction' 44(4) Court journal: The Journal of the American Judges Association, 2007, 7.

46 Berman G, 'Problem-solving courts: A brief primer', 125-140.

47 Berman G, 'Problem-solving courts: A brief primer', 125-140.
} 
simply passing off the case or ignoring it. A problem emerges here when you consider the doctrine of functus officio which is (when) the trial court has completed all its matters vis-à-vis the matter before it. ${ }^{48}$ However, this is a general rule not applied strictly. For example, 'appeal of an interlocutory order has been held to void the subsequent trial that proceeded despite the pending appeal, but in other cases the subsequent trial that proceeded during the pending appeal was upheld'. ${ }^{49}$ Having TJ as an exception to the general rule, in certain circumstances, could be beneficial to Kenya's judicial system as a whole.

The idea that we should have criminal rules just because certain conduct merits punishment or for the good of society is backward in this day and age. When a judge is more involved with a case than he traditionally is, his approach is more informed. For the sake of the rule of law, this should be restricted only to problem-solving courts.

The courts should focus less on the gravity of the crime committed and instead, on the mental health of the criminals themselves. As stated by Vivienne Topp 'this allows the court to take account of the social needs an individual may have and to facilitate compliance with treatment assessed as necessary'. ${ }^{50}$

She further states that 'the application of specialised courts would lead to individual sentencing options and not broad approaches on the matter. ${ }^{51}$ Doing this would encourage individual growth and development, which is key to rehabilitation. In order to apply problem solving courts to the Kenyan legal system, the specific courts themselves should be understood.

\section{a. Drug Treatment Courts (DTC)}

In the US, TJ is manifest through the drug treatment courts. This is quite a valid example in that, as is well known, drug abuse is a widespread problem in the US. ${ }^{52}$ To better illustrate this focus shall be on the DTC's of Texas State.

Firstly, a DTC can be defined as a type of court 'using the authority of the criminal justice system in collaboration with drug abuse treatment in order to reduce drug related recidivism and crime'. ${ }^{53}$

\footnotetext{
48 Fowler T, 'Functus officio:Authority of the trial court after notice of appeal' 81(6) North Carolina Law Review, 2003, 2333.

$49 \quad$ Fowler T, 'Functus officio, 2333.

50 Topp V, 'Specialist courts - The impact upon the individual', 2.

51 Topp V, 'Specialist Courts - The impact upon the individual', 4.

52 Wilson C, ‘5 charts that show how bad America's drug problem is’ Time, 29 March 2016.

53 Stephen T, 'Texas drug courts: Are the ten key components being utilised?' Applied Research Proj-
} 
It differs in many ways from the typical criminal court. First, its main focus is on rehabilitation and not punishment. ${ }^{54}$ Second, one is not required by law to have their case handled by a DTC as it is totally voluntary. ${ }^{55}$ Third, the offender is monitored by counsellors and case managers, not by correction agencies. ${ }^{56}$ Fourth, the disposition of an offender, unlike in criminal courts, is not determined by their criminal history but rather their compliance with treatment ${ }^{57}$ and, lastly, supervision is not only during their incarceration, like in criminal courts, but also after to reduce the chances of the offender relapsing. ${ }^{58}$ To quote Bill Clinton:

'I was so inspired by my personal experience watching your drug court here, and the Attorney General's experience when she took office, that we have worked hard to help others establish drug courts around America. There are now more than one hundred of them in the US. And I think every community ought to have one, and we're going to keep going until every community has the chance to have one. ${ }^{59}$

The typical treatment of drug abusers, in Kenya, for example, is that as soon as guilt is confessed, the accused is sentenced to a jail term for an offence that does not merit that lengthy time period that the judges confer. For example, possession of narcotics, excluding marijuana, warrants imprisonment of twenty years and a fine of not less than one million Kenyan Shillings or three times the market value of the drug. ${ }^{60}$ As soon as their jail term is over, more often than not, they revert back to their destructive habits. In fact, 'experience has shown that various preventative and punitive measures such as fines, imprisonment or detention for drunkenness and other disorderly behaviour have failed in eliminating this menace. ${ }^{61}$

Kenya has drug treatment centres whose focus is on rehabilitation. They have no influence on what the accused's court proceedings may be and this is a vital condition to the rehabilitation of an offender. Realistically, if a drug offender is sentenced to a twenty years' jail term, their incentive to recover would be practically non-existent.

ect, Texas State University, 2009.

54 Martinez A and Eisenberg M, 'Overview of drug courts in Texas' Criminal Justice Policy Council, 2002.

55 Martinez A, 'Overview of drug courts in Texas'.

56 Martinez A, 'Overview of drug courts in Texas'.

57 Martinez A, 'Overview of drug courts in Texas'.

58 Martinez A, 'Overview of drug courts in Texas'.

59 Clinton W, 'Remarks on the national drug control strategy in Coral Gables.', Florida, April 29, 1996.

60 Section 3(2), Narcotic drugs and psychotropic substances (Act No 4 of 1994).

61 Chesang R, 'Drug abuse among the youth in Kenya' 2(6) International Journal of Scientific and Technology, 2013, 130. 
In DTCs, guilt is first confessed and then the court asks if the drug user would like to rehabilitate themselves with the court's help. A behavioural contract is then established between the court and the accused. This behavioural contract entails that the defendant accepts and acts in a particular manner after his or her confession and thereby the sentence is delayed through probation. To quote a relevant source:

'The best part is that the accused is not forced to come to the DTC and enter a behavioural contract (but) instead ... the drug addicts appearing in regular court are asked if they wish their rehabilitation and treatment were supervised by the DTC. If the consent is given voluntarily, the file of the accused is transferred to the DTC and accused is not sentenced to imprisonment or fine on confession. ${ }^{62}$

DTCs would fit into the Kenyan legal system effectively by taking the barebones structure of drug treatment courts in the US. An ideal example would be the Baltimore City DTC which works, and can be adapted to Kenya, in the following manner. Once an offender is caught committing a drug related offence, they are given two options. Whether they would want their case dealt with by a DTC or a magistrate. Before they make this decision they must be eligible. They should be eighteen years and above and they should be Kenyan citizens. Furthermore, they should not have prior convictions for violent offenses.

Should they choose the DTC, a lawyer should be assigned to them if they have none. A test would then be administered to evaluate their suitability for the programme and determine the extent of their addiction. It is administered by a DTC assessment unit which can then determine if this particular offender is a valid candidate for the DTC. All the respective parties can then appear before the DTC judge to discuss the defendant's case. After the case, the judge can then determine if the offender goes into the DTC programme or if they are directed to the magistrate's court where the case would be heard afresh. ${ }^{63}$

\section{b. Mental Health Courts}

In Kenya's justice system, jails and hospitals have become the solutions for those that are suffering from mental illnesses. ${ }^{64}$ However, is this an effective remedy?

62 Munir A, 'Therapeutic jurisprudence and legal education in Pakistan: A quest for innovation in study of law to mend attitudes of law professionals towards litigants.' Pakistan Law Journal, 2008.

63 Gottfredson D, Kearley B, Najaka S, Rocha C, 'How Drug Treatment Courts Work' 44(1) Journal of Research in Crime and Deliquency, 2007, 12.

64 Matata L, 'Kenyans living with mental illness get lost in the criminal justice system' The Star, 18 November 2016 -http://www.the-star.co.ke/news/2016/11/18/kenyans-living-with-mental-illnessget-lost-in-the-criminal-justice_c1458505- on 15 December 2016. 
Jails and prisons offer twenty four-hour, seven-day-a-week supervision and housing, but they were never intended to be psychiatric hospitals. And they are not typically institutionally equipped, trained or staffed to address the treatment needs of people with mental illness. ${ }^{65}$

Further, 'many ex-offenders with mental illness find themselves back in the criminal justice system again in short order' ${ }^{\text {'6 }}$ It becomes a sort of 'revolving door ${ }^{67}$ in that the mentally ill convicts are constantly finding themselves back in prison as soon as they are released. Mental Health Courts (MHCs) aim at putting an end to this vicious cycle. In Kenya, this is a prevalent phenomenon as mentally ill offenders constantly find themselves at odds with the law for petty offences. ${ }^{68}$ Furthermore, imprisonment aggravates the state of mentally ill prisoners and thus is detrimental to their recovery. Because of the lack of knowledge on mental health in prisons, these mentally ill offenders 'receive insufficient care and suffer at the hands of prison officers who mistake them as being rude, uncouth, lazy or unruly. ${ }^{69}$

MHCs are a type of problem solving court that combine judicial supervision with community mental health treatment and other support services in order to reduce criminal activity and improve the quality of life of participants. ${ }^{70}$

There has been a 'shifting of responsibility onto the criminal justice system for the provision of basic healthcare services. ${ }^{71}$ The response, to this shift, was the development of MHCs. They only handle cases involving offenders with mental disorders. In MHCs 'the judge prosecutor, defence attorney and other court staff often have special training in and are familiar with community mental health'. ${ }^{72}$

65 Denckla D, 'Rethinking the revolving door: A look at mental illness in the courts' Centre for Court Innovation (2001).

${ }^{66}$ Barr H, 'Prisons and jails: Hospitals of last resort - The need for diversion and discharge planning for incarcerated people with mental illness in New York' Correctional Association and Urban Justice Centre, 2001.

${ }_{67}$ Denckla D, 'Rethinking the revolving door: A look at mental illness in the courts'.

68 Matata L, 'Kenyans living with mental illness get lost in the criminal justice system' The Star, 18 November 2016.

69 Sereria H, Assessment and treatment of special needs offenders, International Training Course Participants Papers, Resource Material Series Number 94, 2013, $220-<$ http://unafei.or.jp/english/ pdf/RS_No94/No94_PA_Sereria.pdf>- on 15 December 2016.

70 http://www.courts.ca.gov/5982.htm on 9 February 2016.

71 Schneider D, 'Mental health courts.' Wiley encyclopedia of forensic science, 2009.

72 Watson A, Hanrahan P, Luchins D, Lurigio A, 'Mental health courts and the complex issue of mentally ill offenders' 52(2) Psychiatric Services, 2001, 477-481. 
A good example of a country with MHC's in place would be the US where they are located in majority of the states. ${ }^{73}$ There are common sets of goals and procedures created by Derek Denckla that are characteristic to the MHC approach. We can use them to create MHCs in Kenya.

Firstly, MHCs are problem-solving. Denckla states that they are an attempt by court systems to address a systemic problem, taking a look at the issues that defendants with mental illness pose for the courts and crafting a new set of responses. ${ }^{74}$ This, he says, entails that Kenyan courts should become more active in assessing mentally ill defendants and establishing new jurisprudence from their verdicts that will subsequently become statute. This would be essential if MHCs were actually established.

Second, the focus is on public safety. In response to widespread concerns about how courts deal with defendants with mental illness, Denckla states that there should be an attempt to shore up public trust and confidence in the justice system. ${ }^{75}$ This could apply locally if the courts were to take notice of the fragile state of the defendants and, instead of banishing them to already overflowing mental health hospitals, they could play an active role in their recovery. This would imbue trust in the Kenyan court system. This does not mean that courts are better equipped to handle mental health patients as compared to mental health facilities. What it means is that should they choose to work together, the patients' chances of recidivism are greatly reduced. ${ }^{76}$ In Kenya, the mental health judges should be mandated to play a part in the recovery of mental health patients. This does not have to be in a time consuming manner that takes focus away from their main roles but rather through small gestures. For example, these judges can be mandated to make weekly visits to the offenders after the case has been complete. By doing this the courts help in the patient's recovery and, at the same time, remain impartial.

73 Illinois Criminal Justice Information Authority 'A state-wide examination of mental health courts in Illinois: Program characteristics and operations' 2015. In Illinois they have nine mental health courts alone, showing the extent to which the state goes to address mental health concerns.

74 Denckla D, 'Rethinking the revolving door: A look at mental illness in the courts'.

75 Denckla D, 'Rethinking the revolving door.

76 Phipps S, The impact of mental health court on a participant's life, McNair research project, 2012 - 2013, 3 -https://www.google.com/url?sa $=\mathrm{t} \& \mathrm{rct}=\mathrm{j} \& \mathrm{q}=$ =esrc $=$ s\&source $=$ web\&cd $=3 \& \mathrm{cad}=\mathrm{rja}$ \&uact=8\&ved=0ahUKEwjP4enA2K3QAhXBy4MKHWfGAHEQFggoMAI\&url=httpspercent 3 Apercent2Fpercent2Fminds.wisconsin.edupercent2Fbitstreampercent2Fhandlepercent2F1793percent2F70820percent2FSophiepercent2520Phippspercent2520final.pdfpercent3Fsequencepercent3 D11\&usg=AFQjCNFBTSJRD_fgx7F86PxTPgYdNaG5aw\&sig2=BbkD0R-oIN9EEIhj2PW5dg on 16 November 2016. 
For MHCs to operate, they must know how to identify mentally ill offenders. MHCs develop new systems to identify defendants with mental illness. The point in the criminal justice process at which this intervention occurs varies by jurisdiction. The primary sources of identification are jail staff, family members and defence attorneys. ${ }^{77}$ Usually, it is quite open that the defendant may be suffering from a mental illness in that it would be part of their actual defence. There are instances, though few, where the mental state of the defendant, when they committed the crime, was not obviously apparent. It may have been part of his mens rea, but not clearly so. If MHCs are to play a part in the Kenyan legal system it would involve crafting a system to determine if the defendants are legitimately ill, what mental disease they are suffering from, whether that disease was the reason for the crime that they committed and lastly, what treatment the courts (the mental health clinicians in particular) should suggest for the accused person. MHCs in Kenya could apply this by liaising mental health professionals with police officers at police stations to find the signs of mental health issues in any offenders as soon as they are arrested. This means that they can be directed to the respective courts immediately.

After identification, each court has created eligibility criteria that target a certain type of defendant. Almost all programmes require that defendants have symptoms of severe mental illness and face non-violent, misdemeanour charges. ${ }^{78}$ Locally, we can create this eligibility criteria by analysing the mentally ill patients that have gone through the Kenyan court system and, from that, establish a pattern that we can use to analyse future defendants. Also, to weed out those using mental illness as a 'get out of jail free' card, defendants should be suffering mental illness that would justify the crime that they committed, that crime being non-violent and relating to a misdemeanour. For any felonies, if guilt is proved ,then, established local law should still apply and the accused be detained at the pleasure of the President. In the Kenyan MHCs, this criterion can be established by having a network of correspondence regarding methods of analysing mentally ill offenders. This ensures that ideas are communicated throughout the Kenyan legal system.

Lastly, each MHC has a dedicated judge and additional specialised staff. The specialised staff are usually mental health clinicians who screen cases for eligibility, prepare treatment plans, and report to the judge on defendants' progress in

\footnotetext{
Denckla D, 'Rethinking the revolving door.

78 Denckla D, 'Rethinking the revolving door.
} 
treatment. ${ }^{79}$ This would involve, were we to put this into practice in Kenya, having mental health specialists as part of the court system. They would be a vital tool in assessing the defendants and determining if they actually are mentally ill and how severe it may be. Generally, their work would be anything beyond the capabilities of a judge.

\section{iii. The role of judges in problem-solving courts}

Judges in problem-solving courts have a greater mandate than those in traditional courts. Judges in traditional courts must be: independent, impartial, competent, observe equality when judging and maintain propriety, in accordance with the Bangalore Principles. ${ }^{80}$ The role of problem-solving court judges goes above and beyond this. These judges 'first and foremost (are) arbiters of fact and law (and) in this new environment a judge may also need to wear the hat of lawyer, sociologist, psychologist and even psychoanalyst'. ${ }^{81}$ This means that for MHCs to work in Kenya, an entirely new subset of judges must be created. These would be mental health judges whose role is strictly limited to MHCs. This is essential in that these judges are specialised in nature. Their knowledge has to relate to the particular problem-solving courts that they operate in. For example, a mental health judge could have requisite knowledge in law and advanced experience in the field of mental health. This can be through a degree in psychiatry, or any other related course, or long-term experience in the field.

For these judges to perform their roles effectively, they must, as determined by James Duffy, have high emotional intelligence. ${ }^{82}$ This was a trait recognised by Howard Gardner ${ }^{83}$ and can be defined as 'the subset of social intelligence that involves the ability to monitor one's own and others' feelings and emotions, to discriminate among them and use this information to guides one's thinking and actions, ${ }^{84}$

\footnotetext{
79 Denckla D, 'Rethinking the revolving door.

80 These are principles that are intended to establish standards for ethical conduct of judges. They recognise the values: independence, impartiality, integrity, propriety, equality and competence and diligence.

81 Duffy J, 'Problem-solving courts, therapeutic jurisprudence and the constitution: If two is company, is three a crowd?' 35 Melbourne University Law Review, 2011, 395.

82 Duffy J, 'Problem-solving courts, therapeutic jurisprudence and the constitution: If two is company, is three a crowd?'

83 Gardner H, Intelligence reframed: Multiple intelligences for the 21 $1^{\text {st }}$ century, Basic Books, 1999, 43.

84 Salovey P and Mayer J, 'Emotional intelligence' 9(3) Imagination, cognition and personality, $1990,189$.
} 
Particularly, judges in these courts would need to have emotional selfawareness and emotional self-regulation. The former 'involves a conscious step towards understanding what emotions are being experienced' while the latter is 'the skill of regulating behaviour based upon these emotions'. ${ }^{85}$ This means that a judge must be aware of the emotions felt by the participant in the court while at the same time being aware of his own emotions. This determines how he perceives the information received from the participant. They also need to self-regulate emotions in that, should he not do so, they may act in a manner that is detrimental to the state of the participant. For example, if the judge sympathises, rather than empathises, with the participant, his opinion may come out as biased. If they regulate their emotions, then it is easier to process them and act in a rational manner. This means that these judges 'must ensure that their active and very personal involvement with participants does not compromise their individual behaviour and the processes they must administer'. ${ }^{86}$

\section{Mainstreaming TJ in Ordinary Courts}

For most countries, it is not entirely possible for them to establish new courts from the ground up. It may not be cost-efficient especially for countries that are not at their most financially stable, Kenya being a good example. ${ }^{87}$ While Kenya's economic growth may be strong, ${ }^{88}$ the focus is on the creation of high productivity jobs. ${ }^{89}$ Applying problem-solving courts is a great financial endeavour and the Kenyan economy has greater concerns. For example, in the Multnomah County in Oregon, it costs 5,297 US dollars per participant. ${ }^{90}$ The operating costs of the magistrate courts, taking away salaries and utilities amounts to thirteen million Kenyan Shillings. ${ }^{91}$ This translates to twenty four participants, which is not feasible at all.

85 Duffy J, 'Problem-solving courts, therapeutic jurisprudence and the constitution: If two is company, is three a crowd?', 423.

86 Duffy J, 'Problem-solving courts, therapeutic jurisprudence and the constitution, 424.

87 <https://www.centralbank.go.ke/uploads/financial_sector_stability/2057936782_Financialpercent20Stabilitypercent20Rptpercent202015.pdf> on 13 December 2016.

88 Kenya economic update report, Kazi ni kazi, March 2016, 43.

89 Kenya economic update report, Kazi ni kazi, March 2016, x.

90 https://www.ncjrs.gov/pdffiles1/nij/grants/203558.pdf. A detailed cost analysis in a mature drug court setting: A cost-benefit evaluation of the Multnomah county drug court, July 2003, II.

91 http://www.treasury.go.ke/component/jdownloads/send/6-budget/225-recurrent-budget2016-17-book-volume-ii.html, Estimates of recurrent expenditure of the government of Kenya, June 2016, 916. 
There is the option of, rather than leave TJ to specialised courts, to institute it in already existing courts. This is especially cost effective. Instead of establishing new DTCs or MHCs Kenyan courts could instead be modified to suite TJ principles and doctrines.

Wexler, the father of TJ, has already established a theory for this, calling it 'a wine and bottle' approach. The bottles in this case would be, metaphorically, the rule of law and legal procedures (the legal landscape or structure). The wine would be the roles of the legal actors themselves.

Mainstreaming would involve 'examining the provisions of local law (bottles) to see if they are compatible with the use of TJ behaviours, practices and techniques'. ${ }^{92}$ The wine would be the TJ professional practices and techniques. ${ }^{93}$ This would involve analysing existing provisions and determining if it is indeed possible to adapt the doctrines of TJ to them and expect them to function accordingly.

The concept can be analysed by breaking it into two. Wexler conceptualised them as wine and bottles. Using wine meant that judges play a more active role during the case by trying to understand the parties at a level that goes beyond mere court formalities. In doing this, the judge can put himself/herself in the shoes of the accused in order to determine what they would have done, by being the reasonable man, if they were in that situation and thus give a more informed decision. This, however it seems, does not warrant changing the entire way in which judges make decisions. The judge takes this active role by examining the life lived by the accused critically. The judge considers established case-law and, subjectively, the accused. One could argue that judges already have enough on their plate and thus asking them to personally get involved with the parties would be going above and beyond his call of duty. However, if TJ were to actually be effective then judges should try their best to understand their corresponding parties. This would introduce a whole new aspect that would be revolutionary in Kenyan courts.

Bottles are, as earlier quoted, the governing legal rules and procedures. This could be applied by changing the 'game' instead of changing the 'players'. Instead of developing new courts, the rules and procedures of Kenyan courts can be modified to have them fit the doctrines of TJ. TJ, here, would fill the spaces left

\footnotetext{
92 Wexler D, "New wine in new bottles: The need to sketch a therapeutic jurisprudence "code" of proposed criminal processes and practices' Arizona Legal Studies, 2014.

93 Wexler D, 'New wine in new bottles, 464.
} 
by the law governing administrative proceedings. ${ }^{94}$ Wexler differentiates the types of bottles accordingly:

'Bottles vary, too, according to whether they are 'clear or cloudy' - whether they are straightforward and simple to understand or whether they are ambiguous. From a TJ perspective, some of the most interesting bottles are cloudy in the sense that, on initial reading, they may appear to be rather "TJ-unfriendly," but, on closer analysis, they may be susceptible to a practical interpretation consistent with desirable TJ practice'. ${ }^{95}$

However, it is important to note that for TJ to be truly effective then both the 'wine' and the 'bottle' should come together. The roles of the legal actors have to be suited to the legal structures. The wine has to suit the bottle and the bottle needs to suit the wine.

There are ways for us to either use the 'wine' or 'bottle' in the Kenyan jurisdiction. Using 'wine' can be done in a manner of ways. For example, 'less complex language can be used and other communication options, such as openended questions, story-telling, diagrams and role-play, employed'. ${ }^{96}$ This can be done in magistrates' courts where the kind of language used by the judge may not be understood by the accused persons. In these courts, due to the backlog of cases and the number of people in remand, cases are often rushed with the view of dealing with as many litigants as possible. ${ }^{97}$ However, by using simple language (or the language the accused understands best) their cases can be handled in a more efficient manner because of their increased interaction. A more complex manner of using 'wine' would be instituting the problem-solving courts elaborated upon earlier.

It is also possible to use the 'bottle' to install TJ in the Kenyan jurisdiction. Here, the rules of procedure can be modified to suit the principles of 'TJ. Wexler categorises them as 'TJ-friendly' provisions, 'TJ-unfriendly' provisions and the grey area in between as 'TJ-fair weather provisions'. To quote him:

94 Wexler D, 'From theory to practice and back again in therapeutic jurisprudence: Now comes the hard part' 37(1) Monash law review, 2011, 38.

95 Wexler D, 'Moving forward on mainstreaming therapeutic jurisprudence: An ongoing process to facilitate the therapeutic design and application of the law.' Arizona Legal Studies, 2014, 15.

96 Bartels L and Richard K, 'Talking the talk: Therapeutic jurisprudence and oral competence' $38 \mathrm{Al}$ ternative Law Journal 31, 2013, 33.

97 Mboya A, 'Case backlog weighing down justice in courts' Standard Digital, 17 October 2013 $<$ http://www.standardmedia.co.ke/article/2000095690/case-backlog-weighing-down-justice-incourts> on 17 November 2016. 
'A stiff mandatory sentence or a sentence of life without parole ("LWOP") would be quite TJ unfriendly, whereas, virtually by definition, provisions authorizing problemsolving courts would be highly TJ friendly; and fair weather friends are those where a creative and skilled judicial glass-blower has twisted and combined bottles so as to enable unfriendly ones to become friendlier'.98

An example of a TJ-friendly provision from Kenyan law would be Section 26 of the Penal Code which states that in lieu of imprisonment a person may be sentenced to pay a fine instead. ${ }^{99}$ This is TJ-friendly in that it nullifies the effect of a strict mandatory sentence in certain special circumstances. By virtue of it shifting away focus from incarceration, it upholds the principles of therapeutic jurisprudence.

A TJ-unfriendly provision would be Section 3 of the Narcotic Drugs and Psychotropic Substances Act which, as mentioned earlier, states that the punishment for being in possession of narcotics or psychotropic substances for their own personal use is imprisonment for twenty years or a fine not less than one million Kenyan Shillings or three times the market value of the drug, whichever is greater. This is a TJ-unfriendly provision in that even when an alternative is offered to imprisonment, the crime is not proportional to the punishment prescribed.

If the aim becomes to unify the 'wine' and the 'bottle' then the 'bottle' should accommodate the 'wine.' This means that, in the same way that wine can be simplifying the language or using diagrams in magistrate courts, this can be codified into the law. For example, in accommodating for the mentally ill (involved in the court process) the law can determine what kinds of images or role play should be used. Doing so helps the person better understand and communicate to the court and codifying it makes it more efficient for the judges.

Also, in problem-solving courts, an instance of the 'bottle' can be codifying the circumstances when an accused person should go through a traditional or problem-solving court. Setting a criterion on this makes the court process more efficient as a whole. Also, the law can be used to determine the types of remedies that are available in these courts, should they be legal or equitable.

\footnotetext{
98 Wexler D, 'New wine in new bottles: The need to sketch a therapeutic jurisprudence "code" of proposed criminal processes and practices', 464.

99 Section 26, Penal Code (Chapter 63 of 2014).
} 


\section{Challenges Facing TJ}

There are a number of challenges that face the application and mainstreaming of TJ doctrines. One key challenge is that it is hard to evaluate if a particular form of $\mathrm{TJ}$ is effective. ${ }^{100}$ In a scientific experiment, the results are clear for everyone to see. In this case, it is difficult to determine if the TJ doctrine in play is actually working. For example, in an MHC, it is difficult to tell if the involvement of mental health judges in the offender's recovery actually contributes to their recovery. This can be remedied by forming institutions whose role is to evaluate the effectiveness of therapeutic jurisprudence applied in the legal system. With this level of thoroughness, the nuances in different methods can be discovered.

Another challenge facing therapeutic jurisprudence is the creation of problem-solving courts. Existing members of the judiciary may be reluctant to introduce problem solving courts as they may view them as imposing on their roles. However, statistics show that a large percentage of judges are not averse to these kinds of courts. Some, in fact, volunteer themselves for the role of problem-solving judges. ${ }^{101}$ These judges can be found from the existing roster by focusing on those that have practical experience in that particular field. For example, if a magistrate has dealt with a large number of drug related offences they can be offered a role in drug treatment courts. They would have to first undergo practical training. This training can be procured from problem-solving judges from foreign jurisdictions that could liaise with the Kenyan Government to reach an agreement.

Lastly, applying or mainstreaming TJ may be difficult in countries whose legal systems are already ineffective. Creating problem solving courts means that the already existing courts are functional. Incidences of corruption or bribery would be very detrimental to problem-solving courts in that people's lives are on the line. For example, if an offender in a mental health court could pay a judge to release him/her then the problem of the 'revolving door'102 would remain. While the corruption allegations are many in the Kenyan Judiciary, ${ }^{103}$ it is still

100 Robert L and Indermaur D, 'Key challenges in evaluating therapeutic jurisprudence initiatives' $3^{\text {rd }}$ International Conference on Therapeutic Jurisprudence, Perth, 7-9 June 2006, 4.

101 Berman G and Feinblatt John, Good courts: The case for problem-solving courts, Quid Pro Books, New Orleans, 2015, 68.

102 Denckla D, 'Rethinking the revolving door.

103 Karanja F, Makana F and Muthoni K, 'How big shots use courts to frustrate corruption cases and delay justice' Standard Digital, 21 March 2016 -<https://www.standardmedia.co.ke/article/2000195578/how-big-shots-use-courts-to-frustrate-corruption-cases-and-delay-justice $>$ on 15 December 2016. 
possible to have problem-solving courts. This would mean creating an entirely new division dedicated just to problem-solving courts. This division would have new judges but still be under the Judicial Service Commission. The employment of judges shall still be regulated by them but they shall be vetted with the aims of problem-solving courts in mind. For example, whether they have the requisite qualifications and experience for the role. Allegations of corruption or bribery should be dealt with sternly and corrupt persons should be automatically deemed ineligible for the position.

\section{Conclusion}

TJ has the potential to increase the effectiveness of the Kenyan legal system. It would ease the pressure on overpopulated prisons and streamline the working of courts. The best use of TJ would be mainstreaming it. This would be the most effectual way to incorporate TJ and for this, the Kenyan legal system would be for the better. 